\title{
Epilogue: The Aesthetics and Politics of Multilingualism among the Saamaka
}

\author{
Richard Price and Sally Price
}

This wide-ranging book, which deserves to take its place on the shelf right next to the Atlas of the Languages of Suriname (Carlin and Arends 1992), places mobility, multilingualism, multiethnicity, and identity formation firmly in historical perspective. By exploring the specific statuses (legal, cultural, social) of the various peoples who live in or move through Suriname, the essays highlight the ways in which language and ethnicity have contributed to the country's exceptional diversity. They take us through remnants of its colonial past, the challenges faced by particular groups at particular historical moments, and on into the very present. We would stress that Suriname was a Dutch colony for more than three hundred years and that its institutions and official ideology continue to reflect that legacy. None of the languages (and peoples) discussed in this book-except for Dutch-are recognised or promoted by the State (and as a result some of them are highly endangered). In trying to understand the linguistic situation in twenty-first-century Suriname from the perspective of ethnicity, identity, class, and nation-building, this history continues to weigh heavily.

The chapters are diverse, from a large-scale survey of multilingualism and identity among children (Léglise and Migge) to fairly technical linguistic descriptions that nonetheless give the lie to an equivalence of language and ethnicity (Yakpo, van den Berg and Borges, and Yamada), to rich ethnographic accounts of transnational commerce and mobility along the Marowijne (de Theije), complexly shifting ethnic identities, attributions, and nomenclature among Amerindians (Carlin and Mans), analyses of centuries-long migration and transnational mobility by the Kari'na (Collomb and Renault-Lescure), descriptions of the modern globe-spanning migration of Chinese (Tjon Sie Fat) and the multi-sited, circulatory migration of Haitians (Laëthier), the linguistic practices and identity among hybrid Amerindian migrant groups in Western Suriname (Yamada), and the role of new communicative technologies among Maroons (van Stipriaan).

We take the opportunity to participate in this already-rich pepperpot by signaling a few supportive reflections from our own long-term association with

(C) RICHARD PRICE AND SALLY PRICE, 2015 | DOI 10.1163/9789004280120_012

This is an open access chapter distributed under the terms of the Creative Commons Attribution-

Noncommercial 3.0 Unported (CC-BY-NC 3.0) License.

Richard Price and Sally Price - 9789004280120 
Saamaka Maroons, pointing particularly to the role of play and the aesthetic enjoyment of multilingualism, since it has not been dealt with in any depth in previous chapters.

The ethnic diversity and multilingualism of the people of Suriname, as demonstrated in this book, runs counter to the official assimilationist, monolingual (Dutch)-promoting attitudes often expressed by the State. During a 1992 trial before the Inter-American Court for Human Rights (Aloeboetoe $v$ Suriname), one of the justices, Judge Julio A. Barberas of Argentina, questioned Suriname's representative, Judge Advocate Ramón de Freitas, about the linguistic competence of Saamakas, who had brought this case against the State after a number of young, unarmed Saamaka men had been assassinated by Suriname's military.

JUDGE BARBERIS: If, as you said, the national law now applies to Saramakas, how were they made aware of it? Is there a Saramaccan translation of the civil code?

DE FREITAS: The official language of Suriname is...

JUDGE BARBERIS: That's the reason for my question! Answer me yes or no. Is there a Saramaccan translation of the civil code?

DE FREITAS: No.

JUDGE BARBERIS: Right. Well then how can the Saramaka population be acquainted with the laws of Suriname?

DE FREITAS: By means of Dutch, which they learn in school. JUDGE BARBERIS [skeptically]: Most Saramakas speak Dutch?

DE FREITAS: They speak Dutch as far as I know, but especially since $1986 .{ }^{1}$

Given that 1986 marked the beginning of the Suriname Civil War, during which those few schools that had existed in the interior of Suriname were closed for many years, the claims of de Freitas become especially ironic — as well as mendacious.

Fifteen years later, in the yet more important case before the same court, Saramaka People vs. Suriname, language again played a key role. The lawyers for the State consistently argued that Saamakas had now become "assimilated" and were no longer culturally different from other Surinamerslinguistically as well as in other ways. ${ }^{2}$ The first dramatic moment came when

1 From the official transcript of the trial. Further details can be found in R. Price 2011.

2 The State had long viewed whatever rights it granted to Maroons and Indigenous people as temporary protections conceded by the State for a transitional period during a period of their assimilation into the larger, and inherently superior, Surinamese society and economy (Kambel and MacKay 1999). 
Saamaka Headcaptain Wazen Eduards took the witness stand. The president of the Court, Judge Sergio García Ramírez of Mexico, addressed the Saamaka dignitary.

PRESIDENT GARCía RAMíREZ (speaking in Spanish): Mr. Witness, do you swear or solemnly declare upon your honor and conscience that you will speak the truth, the whole truth, and nothing but the truth? HEADCAPTAIN WAZEN EDUARDS (leaping to his feet in his bright yellow Saamaka cape and stretching both arms toward heaven, speaking in Saamakatongo): ${ }^{3}$ I stand before you and the Great God. I have come here today to talk about the poverty and oppression of my people which has been caused by our brothers from the city. We all came over from Africa together. We are brothers yet our particular rights have been violated. We are deeply aware of the injustice. I stand before you and before the Great God because he is the one who made all the birds, all the animals, all the things in the entire world. He is the one we are standing before today. I speak nothing but the truth. There is nothing aside from the truth that I have to tell you today.

This surprising outburst in Saamakatongo-everyone had expected a simple "Yes" - suddenly made clear to the Court that it was dealing here with a people who, despite the claims of the State, were culturally distinct and that language was undeniably a part of their distinctiveness.

And in its landmark judgment of 2007, which recognised the Saamaka People as a legal entity, recognised their traditional territory as belonging to them (rather than to the State), and required the State to make various changes in its laws regarding Maroons and Indigenous Peoples in Suriname, the Court insisted on these peoples' rights to "enjoy their culture" and to pass it on to their children. Indeed, a great deal of recent international jurisprudence makes clear that the freedom to use one's language is one of those fundamental human rights. ${ }^{4}$

3 During the proceedings Sally Price sat next to each Saamaka witness in the box and served as official simultaneous interpreter between Saamakatongo and English, Spanish, and Dutch. For a detailed account of the 2007 trial, see R. Price 2011.

4 See, for example, Un Human Rights Committee, Article 27 of the International Covenant on Civil and Political Rights, which says, in effect, that minorities should not be denied the right to enjoy their culture. 
When in 1968, Maroons of the interior were for the first time invited to participate in national elections, the ruling party, led by Afro-Surinamers ("Creoles") who needed their votes to counter the demographic rise of the Hindustani population, created and promoted the label "Boslandcreolen" in order to erase the identitarian difference between Creoles and Maroons that was so clearly reflected in the traditional term "Bosneger." (In that case, the new term did not stick.) A more recent example of the political power of linguistic and ethnic labels concerns the creation of the term "Bushinenge." Aluku Maroons, who constitute a privileged minority of the Maroon population in French Guiana, with French citizenship and representation in the Conseil Régional and Conseil Général, began promoting this term in the 1980 s in order to seem to be speaking for all Maroons. The term, with its very un-Saamaka "sh" sound, is opposed by Saamakas in French Guiana, who correctly understand it as an attempt at political appropriation.

Today, there are some 80,000 to 90,000 people whose first language is Saamakatongo. ${ }^{5}$ That language (like all languages) is in constant flux, and Saamakatongo now includes lexical items and ways of speaking adopted during the twentieth and twenty-first centuries from external sources such as Sranantongo, Ndyuka, French, Dutch, and more recently Brazilian, Chinese and Russian - the latter because of the new Soyuz base in French Guiana, where many Saamakas are employed. But even beyond that, and in addition to all the second languages mentioned in this book, Saamakas master, to variable extents, an array of ritual languages and generation-specific play languages not unlike Urban Youth Languages found elsewhere (Kießling and Mous 2004) that expand their linguistic repertoires enormously and add to the intellectual and aesthetic pleasure of language use.

Saamakas' appreciation and cultivation of multilingualism has always been an important part of Saamaka life. Indeed, as Kamau Brathwaite has argued (1971: 237), "It was in language that the slave was perhaps most successfully imprisoned by his master, and it was in his (mis-) use of it that he perhaps most successfully rebelled." Saamakas, like other Maroons and their slave ancestors, have always used languages for purposes of secrecy. ${ }^{6}$ Saamaka

5 See R. Price 2013b for the latest figures on Maroon demography. For Saamaka children born in the Netherlands or the United States, Saamaka is often a second or third language. Saamaka parents in Rotterdam, for example, have sponsored Saturday morning classes in Saamakatongo so that their children do not abandon the language.

6 Or even discretion. In order to explain the identity of a Haitian sitting near us at a wake, a Saamaka told us, when we inquired, that he was a "Baka seibi" (an "After-seven" person). This spontaneous label was easily understood by anyone who spoke Saamakatongo (but not 
ritual languages, like those used by other Maroons, are known by specialists who have spent years learning them. They include Apintii drum language, the Papa language sung at funerals, the language of Komanti warrior spirits, that of Wenti sea spirits, that of Apuku forest spirits, and several others. Much of their lexicons draw on a variety of African languages but they also use words from other Maroon languages as part of their practices of disguise and play. For example, the speech of Saamaka Komanti mediums is heavily infused with borrowings from Ndyuka, and Ndyuka Komanti mediums incorporate words from Saamakatongo in their speech. ${ }^{7}$

Maroons are inveterate transnationals and the ability to get along in a foreign language is a central value. Since the 1860s, Saamaka men have travelled in large numbers to French Guiana to work as canoemen. (As early as 1887 , one group of 100 Saramaka men was reported to be returning home from a nine-year-long stay in Mana. ${ }^{8}$ Today, one-third of Saamakas, men, women, and children, live - often illegally, from a French perspective-in French Guiana.) Men who have spent time working there have always enjoyed showing off and amusing themselves in their home villages in Suriname by conducting boisterous conversations in French Creole.

Since the late nineteenth century, these groups of migrant men, once they returned to Saamaka, have created akoopinas - play languages that only members of the in-group can understand - through selective manipulation of the various languages to which they were exposed. The creation and use of akoopinas dates at least from the late nineteenth century, and may go back even further. During much of the twentieth century, a number of akoopinas were in use at any one time in different villages along the Suriname River, and the practice has been reported among other Maroon peoples as well. ${ }^{9}$ A Saamaka friend once told us about an akoopina from Santigoon (Santigron), a village located near Paramaribo that includes a mixed population of Saamakas and Ndyukas, by saying, "It rearranges in Ndyuka; it rearranges in Sranan; it rearranges in Saamakatongo. So it is mixed.... and it also has things of its own." And he pointed to the way the perceived "sweetness" of particular words influenced the choice of which language to draw on:

by the Haitian), since eight (aiti) comes after seven (seibi) and is pronounced identically by Saamakas to "Haiti."

7 For further discussion as well as hundreds of examples of words, songs, and phrases in these ritual languages, see R. Price 2008.

8 Dosier [sic.] benoeming Akrosoe, Landsarchief, Paramaribo. See, for further history of Suriname Maroon migration, R. Price 1970 and R. and S. Price 2003.

9 For further discussion of akoopinas, see R. and S. Price 1976. 
When you say mbaku, that's from kumba, which is how Ndyukas say "navel." If you reversed it in Saamakatongo, it would be gonbi (from bingo), but when you are really talking the language, you must say mbaku, because it's the language with the sweetest name for a thing that you must take. If Saamaka is sweeter, you use that; if Ndyuka, you use that; if Sranan, you use that.

Although most akoopinas have been used for relatively brief exchanges, there was one, which originated in the mid-nineteenth century in the village of Kampu and was passed on exclusively to residents of Kampu for at least a hundred years, that people used for extended conversations. In the 196os all men and boys in the village as well as a few of the older women were said to speak it fluently. It was based on syllable rearrangement of French Guiana Creole, though many of its speakers had no knowledge of French Creole itself. Examples we were given included "Téku vé-utu" meaning "Where did you find it?" from Creole "Koté u tuvé?" Or again, the word for "family," which in normal Saamakatongo is the same as the word for belly/womb, became, in this akoopina, "tivan" - a distortion of "vanti" (Saamakas' pronunciation of French Creole vant, which derives from French ventre).

Saamakas' fascination with foreign languages also enlivens popular songs. In 1968 an eleven-year-old boy sang for us a seketi song that evokes a Brazilian greeting, apparently heard by men during labor trips to Kourou, where their coworkers constructing the European Space Center included Brazilians. Combining linguistic bits from these encounters with regular Saamakatongo, the song embellishes them with typical seketi flourishes such as the ideophonic nyelele and a rhetorical allusion to royalty: ${ }^{10}$

Sinyolu, nyenlele, miii

Sinyolu, un yei no?

Sinyolu, bondia-o,

We, ma o yei moo e.

Di mi naki te mi dou

A Degaa konde,

Potugei bakaa ko ta bai

Da mi odi u sembe.

We, nono,

We, a bai da mi odi u sembe.
Senhor, nyelele, child

Senhor, y'a hear now?

Senhor, bom dia

Well, I won't understand the rest.

When I travelled till I arrived at Degras village

a Portuguese whiteman called out and gave me someone's greeting. Well, now, Well, he called out someone's greetings

This is one of 45 song texts discussed in S. Price 1984: 172-187. 

A ko ta bai:
He called out:
O sinyolu,
O Senhor,
Kuma ta vaiwe?
Como te vai? [How are you?]
O katé o katé plaatigo
O que pratico [What I'm saying to you...]
Kutu kutu, Escuta, escuta [Listen, listen]
Sinyolu-konu.
Senhor, king.

In recent decades, one of the primary contexts for sharing language and creating cross-ethnic group solidarity is the flourishing urban pop music scene, which encompasses not only greater Paramaribo but extends to Rotterdam, Amsterdam, and other sites in the Netherlands. In a series of fascinating articles, Kenneth Bilby has documented the influx and influence, since the late 1970s, of young Maroon musicians on the urban scene (see, for example, Bilby 1999, 2001; Bilby and Jaffe, 2009). He writes: "Almost every major trend in grassroots kaseko [traditionally, the Creole-and national-dance music par excellence] since the mid-1980 has been pioneered by Maroon players; most recent kaseko hits in Suriname have been by bands made up primarily or entirely of Saamaka and Ndyuka Maroons" (Bilby 2001: 304). Or, again stressing the international and multilingual influences on Suriname's pop music varieties, as played by bands composed of Maroons and Creoles, he writes:

In any random selection of kaseko, kawina and aleke recordings made during the last ten years, one is liable to detect strains of Jamaican reggae and dancehall, French Antillean zouk, Central African soukous, Haitian kompa, Dominican merengue, South African mbube, Trinidadian soca, North American funk, hip-hop, and house, Brazilian samba, or any number of other foreign styles. (1999: 267)

And discussing what he calls "the cosmopolitan openness displayed by kaseko and kawina bands," he offers that

A good example is "Mani Mani" by Bigi Ting. Prefaced by a bit of Brazilian samba-style drumming, the piece then kicks off in typical aleke style with a section in the Ndyuka language; eventually the melody changes, and the lyrics (quoting a number of hit songs by other Surinamese bands) begin to shift back and forth between Sarnami Hindi, English, Ndyuka, and Sranan; this part of the song alternates with yet another section consisting of an aleke version of James Brown's "Sex Machine," rendered in an approximation of African-American Vernacular English (over typical Ndyuka aleke drumming). (1999: 217 and 290 [note 16]) 
What better example could we wish for of multilingualism from below, the peoples' insistence on their right to use, play with, and develop new linguistic (and musical) resources, across every imaginable border?

The everyday predominance of multilingualism, with children routinely speaking three and four languages, as demonstrated in the chapter by Léglise and Migge, fits squarely with our own, less systematically elicited, impressions among Saamakas. Two of the households in which we have spent time in recent years have impressed upon us the enjoyment as well as the everydayness of both multilingualism and cross-ethnic group relations. In St. Georges, on the French Guianese border with Brazil, sharing a meal with Léon (who was brought up by his Saamaka father rather than his Creole mother), his Creole wife Julie, a Brazilian son-in-law, and various others, conversation around the ample dinner table weaves effortlessly in and out of Saamaka, French Creole, French, and Portuguese, with everyone participating. And at our friend Tooy's house in Cayenne, the mixture tends instead to be Saamaka, Ndyuka, French Guianese Creole, Haitian Creole, Sranantongo, and French, reflecting the various ethnicities of the people who happen to be present on a given day.

Finally, a note about words into text. Although Saamakatongo, like the other Maroon languages, is primarily a spoken language, the development of an orthography for it began soon after the 1762 peace treaty with the Dutch Crown, when German Moravian missionaries first arrived in Saamaka territory. From 1765 until 1813, thirty-seven Moravian men and women attempted to bring their brand of Christianity to the Saamaka. ${ }^{11}$ Writing biblical texts in the Saamaka language was part of this effort, which culminated in a remarkable Saamakatongo-German dictionary (Schumann 1778). Since that time, there have been other attempts to develop an orthography for Saamakatongo- by the linguist Jan Voorhoeve and the R.C. priest Antoon Donicie in the 1960s, by the sIL field linguists Catherine Rountree and Naomi Glock in the 1970s and 8os, and by amateur linguists in French Guiana during the past decade. ${ }^{12}$

During the past several years, working with Saamaka linguist Vinije Haabo, we have developed a new orthography and recently published a book that uses it. ${ }^{13}$ Written at the formal request of the Saamaka People, and using the new orthography with their approval, we hope that this book will serve as the new

11 See R. Price 1990, which explores the relationship between Saamakas and missionaries during the second half of the eighteenth century.

12 See, for example, Donicie and Voorhoeve 1963, Rountree, Asodanoe and Glock 2000, and Lienga 2013 .

13 R. Price 2013a - available in bookstores in Guyane and Suriname and from www.amazon.fr. See also the excellent Saamakatongo dictionary of Vinije Haabo at www.saamaka.com. 
standard for turning the spoken language into written text. ${ }^{14}$ The orthography, which does not use diacritical marks, mimics the one that Saamakas use on their Blackberries, Iphones, and Androids. For speakers of the language-as, for example, speakers of French-it turns out that diacritics are not necessary either for reading or writing the language.

Hats off, then, to this fine collection on language, mobility, and identity! In its anti-essentialist efforts to focus on interwoven social interactions that are constitutive of identity-making processes and changing linguistic practices, it opens the door to a variety of new paths for research and understanding. But in all the emphasis on shifting and contextualised identities, we should never forget that for some peoples, in some circumstances, a notion of ethnicity as fixed and immutable continues to matter. At the 2007 trial before the Inter-American Court, when Suriname's attorneys were trying to assert that Saamaka identity was on the wane and that the authority of the gaama [paramount chief] could not possibly extend to Saamakas who lived abroad, the State's own witness Saamaka Headcaptain Albert Aboikoni (a former representative to Suriname's national assembly) eloquently countered this claim. Speaking in Dutch, he answered them, saying with emotion: "Als woon je op de maan, je ben een Saramaccaner. De gaama is ook gaama van jij"-Even if you lived on the moon, you would still be a Saamaka.

14 The Saamaka People have purchased 3000 copies for distribution in their schools. 